\title{
The Effect of Combination Calcium Hydroxide-Propolis Application to Amount of Neutrophil Cells on Wistar Rat Pulp Perforation
}

\author{
Ira Widjiastuti, Setyabudi and Nia Nur Haliza \\ Department of Conservative Dentistry, \\ Faculty of Dental Medicine, Airlangga University, \\ Surabaya - Indonesia
}

\begin{abstract}
Background: Pulp inflammation can be treated with pulp capping by calcium hydroxide as the gold standard. Pulp capping by calcium hydroxide could causing tissue necrosis followed by inflammation. Calcium hydroxide combined with propolis which have anti-inflammatory effects through inhibition of the Nf-kB pathway and pro-inflammatory cytokines. That process will inhibit the increase of vascular permeability and neutrophil chemotaxis. Inflammatory process can accelerate by controlling the amount of neutrophil cells as a acute phase marker, so the healing process occurs more quickly. Therefore it is necessary to study the amount of neutrophil cells in the pulp perforation of Wistar rats after applicated by combination of calcium hydroxide-propolis. Purpose: To analyze the difference amount of neutrophil cells on the Wistar rats pulp perforation after applicated by calcium hydroxide-propolis combination compared with calcium hydroxide-aquadest Method: M1 tooth perforated for all groups with three types tratment: no medication (control group), calcium hydroxide-aquadest 1: 1 (P-1 group), and calcium hydroxide-propolis 1: 1.5 (P-2 group) and closed with cention. Observations were made on the 1st, and 3rd day with HE staining. Results: One Way ANOVA shown a significant difference $(p<0.05)$ of the average amount of neutrophil cells between all treatment groups on 1 st day $(p=0.000)$ and $3 \mathrm{rd}$ day $(p=0.000)$. The amount of neutrophil cells in the calcium hydroxide-propolis $(P-2)$ combination group was lower than control group and calcium hydroxide-aquadest (P-1) group on the 1st and 3rd day. Conclusion: The amount of neutrophil cells after application of calcium hydroxide-propolis is lower than calcium hydroxide-aquadest application.
\end{abstract}

Keywords: Pulp inflammation, neutrophil cells, calcium hydroxide-propolis

Correspondence: Ira Widjiastuti, Department of Conservative Dentistry, Faculty of Dental Medicine, Airlangga University. Jl. Mayjen Prof. Dr. Moestopo 47, Surabaya, Indonesia, 60132. Email: ira-w@fkg.unair.ac.id

\section{INTRODUCTION}

Inflammation of the pulp is a problems that still often occurs in oral health. According to the results of Riset Kesehatan Dasar (Riskesdas) in 2013, the number of patients experiencing pulp inflammation was 160.000 cases in a year. Inflammation on the pulp can cause by mechanical injury. This mechanical injury can occur due the deeper tooth preparation process that causes trauma. When mechanical trauma causes irritation of the pulp, the body will carry out an inflammatory reaction, which is the body's defense response to the presence an injury. The purpose of inflammatory process is to eliminate the cause of lesions, necrotic cells and tissues so the wound healing process and tissue repair will occur ${ }^{1}$.

Inflammation is a process that needed as a body's defense, but if the inflammation prolonges and excessive it can cause tissue damage and healing process failure. This inflammation can be controlled by accelerating the process of acute inflammation, where the cells marker for acute inflammation are neutrophils. Neutrophils are the most white blood cells that can protect the body against invading organisms, especially by phagocytosis ${ }^{2}$.

In the initial phase of inflammation, accumulation of neutrophils cells into the lesion area is very important to fight decontamination. However, neutrophils that stay at lesion area for a long time cause more damage than repair. Neutrophil's proteinase can decrease proteins important for repair, like clotting factors, complement, cytokines and immunoglobulins. Neutrophils also produce free radicals which cause oxidative stress, damage tissue and delay healing. The loss of neutrophil dominance is a prerequisite for continuing the proliferative phase. According to research before, macrophages are the main key responsible for removing neutrophils in the affected area. Macrophages can induce neutrophil apoptosis, and phagocytosis of neutrophil apoptosis, called eferocytosis process. Neutrophil 
phagocytosis can induce the macrophage phenotype from M1 (pro-inflammatory) to reparative M2 (antiinflammatory) ${ }^{3}$.

Increase the amount of neutrophils that are controlled, and no migration of neutrophils continuously in a long time will cause the healing process to occur more quickly. High neutrophil cell infiltration can stimulate macrophages (M1 pro-inflammatory) into the lesion area, whereas if the amount of neutrophil cells is lower with a short life phase and is immediately apoptosis it can increase Macrophages (M2 anti-inflammatory) and continue healing so the acute inflammatory phase quickly ends ${ }^{4}$. These neutrophils invade the inflammatory area shortly after injury and predominate within 24-36 hours. The amount of neutrophils will decrease with time due to apotosis and their phagocytic function will soon be replaced by macrophages ${ }^{5}$.

The purpose of tooth conservation treatment is to keep the pulp health, including being free from inflammatory or infectious reactions. To achieve this purpose, the pulp tissue must be protected in order to maintain its health and vitality. One kind of therapy to maintain pulp vitality is pulp capping. In the field of dentistry conservation, calcium hydroxide is the gold standard pulp capping. This is because calcium hydroxide can trigger the growth of tertiary dentin and has a high $\mathrm{pH}$ (12.5). However, calcium hydroxide has the disadvantage of causing necrosis pulp surface after pulp capping, high solubility, poor dentin bridge formation, and low mechanical resistance and may cause microfiltration in the future resulting in treatment failure ${ }^{6}$. According to Rosyida's research (2016) ${ }^{7}$ from 30 cases of direct pulp capping treatment with calcium hydroxide, there were only 11 cases that were categorized as successful. Therefore, to increase its effectiveness, calcium hydroxide can be combined with natural ingredients such as propolis which are known to have anti-inflammatory and antimicrobial effects ${ }^{8}$.

Propolis is a natural complex resins produced by Apis mellifera bees. The main content of propolis are CAPE, flavonoids, and quercetin which have anti-inflammatory effect by inhibiting the process of increasing vascular permeability and neutrophil chemotaxis to the lesion area ${ }^{9}$. According to Enggardipta's research (2016) ${ }^{5}$ there was a decrease in neutrophil cell infiltration in pulp perforation due to mechanical lesions seen significantly on 1st and 3rd days after being given an anti-inflammatory agent. Based on this background, a study is needed to determine the effect of combination calcium hydroxide-propolis application to amount of neutrophil cells in Wistar Rat pulp perforation.

\section{MATERIALS AND METHODS}

This study was done at Faculty of Veterinary Medicine Laboratory, Airlangga University, Surabaya and Reseach Center of Dental Medicine, Airlangga University, Surabaya in May 2019 to October 2019 with approval of ethical conduct No.727 / HRECC.FODM / X / 2019 by the Ethics Committee of the Faculty of Dental medicibe, Airlangga University, Surabaya. This kind of research is laboratory experimental study with post test only group design.

The samples of this study were white male rats (Ratus novergicus) Wistar strain with age criteria was 12-16 weeks, 200-250 grams body weight, molar teeth that had grown complately with a healthy physical condition without carious lesions or trauma. This study uses 3 types of treatment, consisting of 6 samples per group and 36 total samples. In the control group the upper right M1 teeth perforated and filled by cention, in the P-1 group the upper right M1 teeth were perforated and applicaed by calcium hydroxide-aquades 1: 1 and filled by cention, while in the P-2 group the right upper M1 teeth were perforated then given calcium hydroxide-propolis 1: 1.5 and filled by cention. The combination of Calcium Hydroxide-propolis used is pure calcium hydroxide powder (Hydroxido de calcio P.A, Brazil) ${ }^{10}$ which has been added by natural propolis extract with $11.45 \%$ concentration by maceration method from Apis sp bees in Lawang Malang, Indonesia. Observations were made on $1 \mathrm{st}$, and 3rd days using HE staining and observed microscopically.

Before treatment, the rats anesthetized intramuscularly with 0.2 cc mixture of $10 \%$ ketamine (Kepro B.V., Deventer, Holland) and xylazine HCL 0.4\% (Xyla®, PT Tekad Mandiri, Bandung, Indonesia). Preparation class I (Black classification) on the occlusal surface of the upper M1 teeth using a handpiece with a round drill (0.8 $\mathrm{mm}$ diameter) with a depth of preparation is about $1.5-2 \mathrm{~mm}$. Cavity is perforated using a straight sonde $(0.46 \mathrm{~mm}$ diameter $)$ with mild pressure, until there is bleeding in the cavity marked by the presence of bloody spots (red spots). After perforation, $0.9 \%$ sodium chloride sterile is applied to the cavity and dried using cotton pellets. Bleeding arising was stopped with sterile paper point cuts (Inline $\AA$, B.M. Dentale S.a.s, Torno, Italy) and continued with treatment according to their respective groups using sonde to applicated by calcium hydroxide-aquadest, and calcium hydroxide-propolis. Then the cavity close uses Cention (Cention N, Ivoclar Viva Dent, Germany) with a ratio of powder and liquid which is 1: 1. After the process was completed, on the 1 st day, and the 3 rd the rats was decapitated and a jaw bone was cut in the interdental area of the right upper maxillary molar. Continuing the process of making preparations with HE staining and examining preparations using a light microscope (Nikon eclipse E200 microscope, Japan) 400x magnification, and made 8 visual field boxes.

The research results analyzed using IBM SPSS 20 statistical software. The normality test uses KolmogorofSmirnof test, the homogeneity test uses the Levene test, then the One Way Anova test to find out the differences between treatment groups, the Post Hoc Test (Tukey HSD) to see the comparison between samples, and Independent T-Test is performed to determine the average group differences based on time factors. 


\section{RESULTS}

The amount of neutrophil cells was observed by anatomic histopathology using a 400x magnification light microscope with hematocycline-eosin staining. The results of observing the amount of neutrophil cells in the pulp perforation of Wistar rat day 1 and day 3 obtained the average amount of neutrophil cells and the standard deviation of each treatment group can be observed in Table 1 .

The average amount of neutrophil cells was highest in the control group, then the P-1 group and the lowest in the P-2 group. This study analyze the amount of neutrophils cells in the Wistar rat perforation pulp on 1st and 3rd day by observing the histopathological picture of the anatomy by HE staining using a 400x magnification light microscope which can be seen in Figures 1 and 2.

In Table 1, Figure 1 and Figure 2, the highest and most dense amount of neutrophil cell 1 st and 3rd days was seen in the control group, followed by $\mathrm{P}-1$ group and the lowest in P-2 group. The average amount of neutrophil cells on 1st day was higher than 3rd day for the entire group, where the control group had the highest average amount of neutrophils and the P-2 group had the lowest average amount of neutrophils.

Based on the results obtained, a statistical analysis of the normality test was carried out with Kolmogorof Smirnov
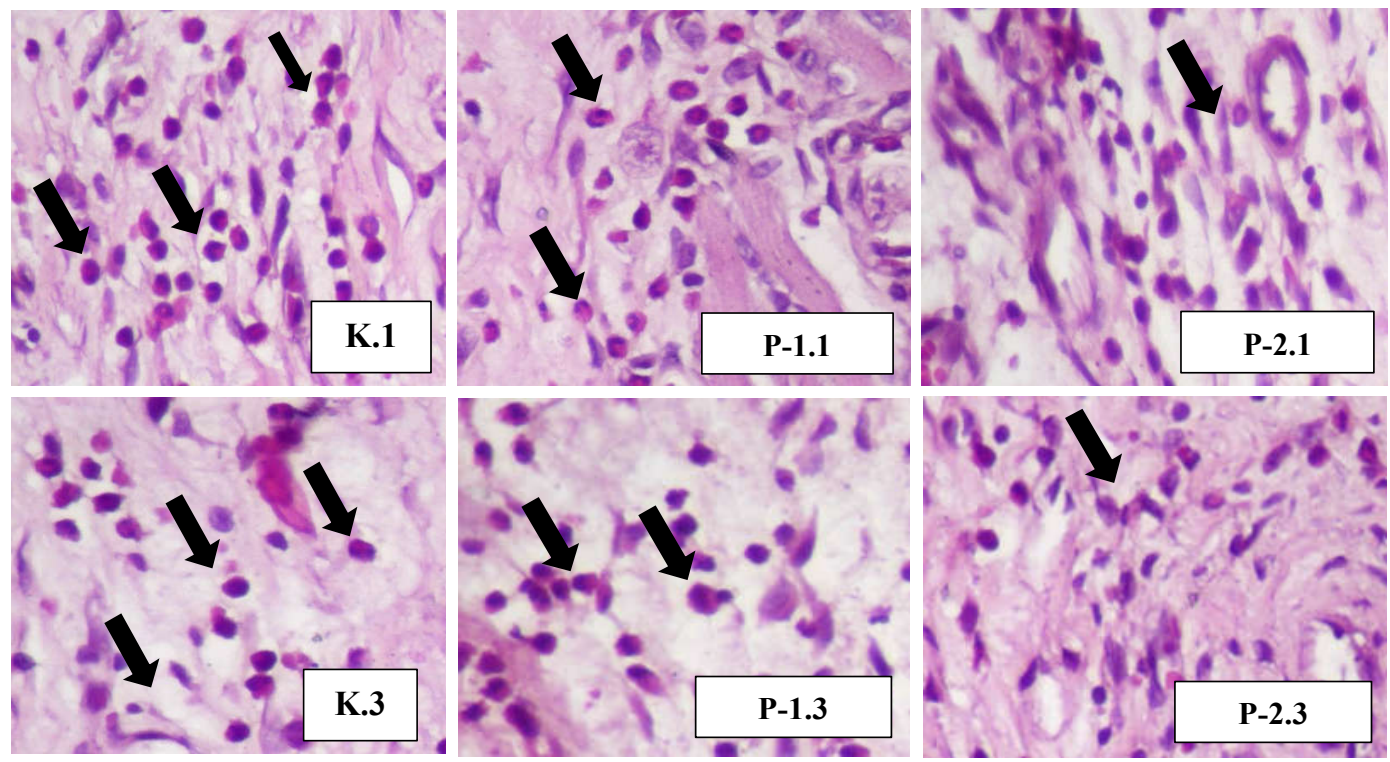

Figure 1. Overview of HPA neutrophil cells in Wistar rat pulp on 1st and 3rd days with HE staining, 400x magnification. (K.1) 1st day control group, (P-1.1) 1st day treatment 1 group, (P-2.1) $1^{\text {st }}$ day treatment 2 group, (K.3) 3rd day control group, (P-1.3) 3rd day treatment 1 group, (P-2.3) 3rd day treatment 2 group. (Black arrows indicate neutrophil cells).

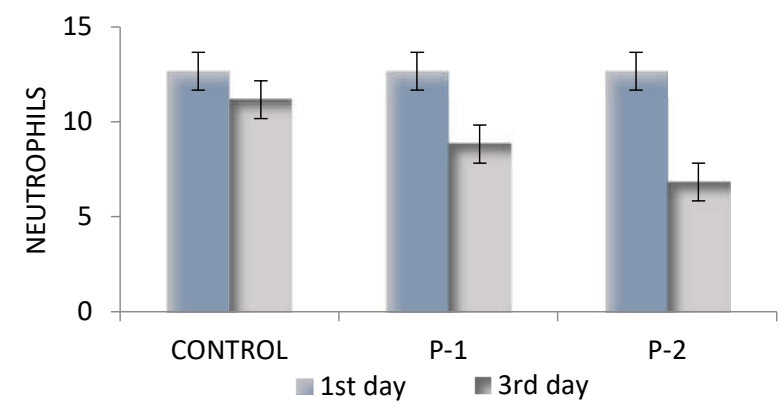

Figure 2. Graph shown the average amount of neutrophil cells in the Wistar rat pulp for all groups on 1st and 3rd days.
Table 1. Average results and standard deviation of neutrophil cell counts in Wistar rat pulp in control and treatment groups on 1 st and 3rd day

\begin{tabular}{lccccc}
\hline \multirow{2}{*}{ Group } & \multirow{2}{*}{$\mathrm{N}$} & \multicolumn{2}{c}{ 1st Day } & \multicolumn{2}{c}{ 3rd Day } \\
\cline { 3 - 6 } & & $\mathrm{X}$ & $\mathrm{SD}$ & $\mathrm{X}$ & $\mathrm{SD}$ \\
\hline $\mathrm{K}$ & 6 & 12.6667 & 1.21106 & 11.1667 & 0.75277 \\
$\mathrm{P}-1$ & 6 & 10.1667 & 1.16905 & 8.8333 & 0.75277 \\
$\mathrm{P}-2$ & 6 & 8.1667 & 1.16905 & 6.8333 & 0.75277 \\
\hline
\end{tabular}

Note: $\mathrm{N}=$ Number of samples; $\mathrm{X}=$ Average; $\mathrm{SD}=$ Standard Deviation;

$\mathrm{K}=$ Control group; $\mathrm{P}-1=1$ st treatment group (Calcium HydroxideAquadest 1: 1$) ; \mathrm{P}-2=2$ nd treatment group (Calcium Hydroxide-propolis $1: 1.5)$

Table 2. Tukey HSD Multiple Comparisons test shown the difference amount of neutrophil cells for all groups on 1st and 3rd days

\begin{tabular}{|c|c|c|c|c|c|c|}
\hline \multirow{2}{*}{ Group } & \multicolumn{3}{|c|}{ 1st day } & \multicolumn{3}{|c|}{ 3rd day } \\
\hline & Control & P-1 & P-2 & Control & P-1 & P-2 \\
\hline Control & & $0.006^{*}$ & $0.000^{*}$ & & $0.000 *$ & $0.000 *$ \\
\hline P-1 & $0.006^{*}$ & & $0.026^{*}$ & $0.000^{*}$ & & $0.001 *$ \\
\hline P-2 & $0.000 *$ & $0.026^{*}$ & & $0.000 *$ & $0.001 *$ & \\
\hline
\end{tabular}


Table 3. Independent T-Test results to amount of neutrophil cells on Wistar rat pulp perforation seen between the same groups on 1 st and 3 rd days

\begin{tabular}{lccc}
\hline Treatment & Control & P-1 & P-2 \\
\hline $\begin{array}{l}\text { 1st day } \\
\text { 3rd day }\end{array}$ & $0.028^{*}$ & 0.113 & $0.045^{*}$ \\
Note: $*$ there is a significant difference $($ p-value $<0.05)$ &
\end{tabular}

and homogeneity with the Levene test which showed normal and homogeneous data distribution, then continued the data analysis with one way ANOVA test. One Way ANOVA test results on 1 st day obtained a significant value $(p=0.000)$, and on 3rd day a significant value was also obtained ( $\mathrm{p}$ $=0.000)$ so there are significant differences between all treatment groups.

Subsequent data analysis used a post hoc test to determine the differences in each treatment group on 1st day and 3 rd day using Tukey HSD test which can be observed in Table 2. All groups on 1 st and 3rd days had $\mathrm{p}<0.05$ when compared to the different treatment groups. This shows that the control group on 1 st and 3rd days had a significant difference to group P-1, group P-2 and vice versa. In group $\mathrm{P}-2$ also has a $\mathrm{p}$ value $<0.05$ against group $\mathrm{P}-1$ so there is a significant difference between P-2 group and P-1 group.

In this study, observations were made for two days (1st and 3rd days) to determine differences in the decrease amount of neutrophil cells for all treatment groups seen by the day. The results of the Independent T-Test data analysis can be seen in Table 3. Independent T-Test results $p=0.028$ for control groups on 1 st and 3 rd days. This result shows a significant decrease in the amount of neutrophil cells from the $1^{\text {st }}$ day to 3 rd day of control group. $p=0.113$ for group P-1 on the 1st day to 3rd days which means there was no significant difference between groups $\mathrm{P}-1$. Test results for P-2 group on 1 st day to 3 rd days showed $\mathrm{p}=0.045$ which means there were significant differences between groups of $\mathrm{P}-2$.

\section{DISSCUSION}

In this study, the amount of neutrophil cells was observed for two days, 1st day and 3rd day after treatment. In all 1 st day groups, the amount of neutrophil cells was higher compared to the whole 3rd day group (Table 1; Figure 1; Figure 2). This is because neutrophil cells invade the lesion area shortly after the onset of injury and dominant at 24-36 hours which is referred to acute phase of inflammation. On 3rd day, there is a physiological decrease in the amount of neutrophil cells because it has begun to enter the chronic inflammatory phase where the role of neutrophils cells is continued by macrophages ${ }^{11}$.

The results of independent T-Test (Table 3) show that the control group on 1st day and 3rd day have a significant decrease which is a physiological process. Significant results were also shown in the P-2 group on 1st day to 3rd day which means that the acute inflammatory phase after application of calcium hydroxide-propolis occurred more quickly. No significant difference results were seen in the P-1 group on 1st day to 3rd day. This shows that the effect of calcium hydroxide material to amount of neutrophil cells is less effective after being observed until the 3 rd day. Calcium hydroxide causes necrotic tissue, can increase the expression of nuclear factor kappa B (NF-kB) and proinflammatory cytokines for 3 days in the pulp tissue that contact directly with $\mathrm{Ca}(\mathrm{OH})_{2}$ material, so it will cause an increase in vascular permeability and neutrophil chemotaxis to the area of injury ${ }^{12}$. High $\mathrm{pH}$ of $\mathrm{Ca}(\mathrm{OH})_{2}$ can cause coagulation necrosis in pulp tissue and persistent inflammation ${ }^{13}$.

The amount of neutrophil cells was observed in three treatment groups (control group, calcium hydroxideaquadest, and calcium hydroxide-propolis). The results showed that the average amount of neutrophil cells in the calcium hydroxide-aquadest (P-1) group was significantly lower than the control group (Table 1; Figure 1; Table 3). Acute phase inflammation that occurs in the control group will be longer than the acute phase inflammation in the calcium hydroxide-aquadest (P-1) group.

In the control group, the pulp perforation would be direct contactly with cention (alkasite). Cention contains resin that causes direct irritation to the pulp. This irritation will cause increase of inflammatory response through the Nf-kB pathway and pro-inflammatory cytokines so it will increase vascular permeability and neutrophil chemotaxis to the lesion area occurs for longer. The monomer content of cention (UDMA) is cytotoxic, can cause cell damage including stopping the cell cycle, cell apoptosis, inflammation and or tissue necrosis ${ }^{14}$.

In the calcium hydroxide group, there will be a release of $\mathrm{OH}^{-}$ions which causes the formation of necrotic tissue as deep as 1-2 $\mathrm{mm}$ in the area around the pulp. The lower part of this necrotic tissue will have a lighter inflammatory response and cells will differentiate into odontoblasts to form a dentin matrix ${ }^{15}$. Calcium hydroxide which causes necrotic tissue can still induce proinflammatory cytokines and increase the expression of nuclear factor kappa B (NF$\mathrm{kB})$ which plays a role in inflammatory reactions ${ }^{12}$.

The results of control treatment and $\mathrm{Ca}(\mathrm{OH})_{2}$ are in accordance with Poimenova (2018) ${ }^{14}$ research which shows that the inflammatory response occurs in rat pulp perforation given resin material is higher than calcium hydroxide. The necrosis zone formed after application of calcium hydroxide is limited to the area of application of the material, where as in the resin application group there is greater damage and distortion in the tissues due to loss of cell viability and tissue integrity so that the resulting inflammation takes longer.

The average of neutrophil cell count in the calcium hydroxide-propolis (P-2) group was significantly lower than the calcium hydroxide-aquadest group (P-1) (Table 1; Figure 1; Figure 2; Table 3). The acute inflammatory phase of the calcium hydroxide-propolis group ends more quickly than the calcium hydroxide-aquadest group. The main content of propolis are CAPE, flavonoids, and quercetin can inhibit the activation of Nf-kB pathway and the release of proinflammatory cytokines such as IL-1, IL-6, IL-8 and TNF- $\alpha$ which affect inflammatory cells activity with inhibiting 
increased vascular permeability, neutrophil chemotaxis, and leukocyte adhesion ${ }^{16}$.

This combination of calcium hydroxide (alkali) and propolis (acid) will physically bind to form hydrogen and Van Der Waals bonds. Calcium hydroxide which releases $\mathrm{OH}^{-}$ions will bind to $\mathrm{COOH}$ from propolis. The combination will have the decrease of $\mathrm{pH}^{10}$. Unlike the calcium hydroxide-aquadest treatment group which has high $\mathrm{pH}$ (12.5). The release of $\mathrm{OH}^{-}$ions will cause tissue necrosis resulting increase in the inflammatory response by increased vascular permeability, and neutrophil chemotaxis into the lesion area. Too acidic or too basic $\mathrm{pH}$ can cause an increase intracellular ROS, high ROS will cause oxidative stress which then occurs cell apoptosis, cell necrosis or cell damage and inflammation ${ }^{14}$.

Research by Ahangari et al. (2014) ${ }^{17}$ showed that the application of propolis with a weak acid $\mathrm{pH}$ in pulp perforation did not indicate pulp necrosis, where as in $\mathrm{Ca}(\mathrm{OH})_{2}$ application a zone of necrosis appeared in the pulp chamber. Pulp necrosis that is formed will increase the inflammatory response that occurs. Other studies have shown that the odontoblast layer formed in the $\mathrm{Ca}(\mathrm{OH})_{2}$ application is thinner than propolis. This is caused by anti-inflammatory properties of propolis which inhibit the translation of the Nf-k $\beta$ pathway in the nucleus to prevent cell apoptosis. Barriers to cell apoptosis result in prevention of a drastic reduction in the number of pulp fibroblast cells. This propolis will stimulate the production of growth factors TGF- $\beta 1$ which will affect the proliferation of fibroblasts for the formation of collagen and odontoblast like cells. The anti-inflammatory properties of propolis can increase the proliferation process ${ }^{13}$.

Based on the discussion above, it is proven that the average amount of neutrophil cells after application of calcium hydroxide-propolis is lower than calcium hydroxide-aquadest application. It caused by antiinflammatory properties of propolis, and $\mathrm{pH}$ decreased of calcium hydroxide-propolis combination material. The acute inflammatory phase of the calcium hydroxide-propolis group end more quickly than the calcium hydroxideaquadest group. In conclusion, the amount of neutrophil cells after applicated by calcium hydroxide-propolis is lower than the amount of neutrophil cells after applicated by calcium hydroxide-aquadest.

\section{REFERENCES}

1. Fatimatuzzahro N. Perubahan Histologis Jaringan Pulpa sebagai Respon terhadap Aplikasi Bahan Etsa. Stomatognatic (J K G Unej). 2015;12(1):5-10.

2. Maya Dyaningsih D, Praharani Bagian Periodonsia Fakultas Kedokteran Gigi Universitas Jember D. Pengaruh Pemaparan
Entamoeba gingivalis Terhadap Jumlah Polimorfonuklear Neutrofil (PMN)Pada Tikus Wistar Jantan dengan Radang Gingiva

3. Landén NX, Li D, Ståhle M. Transition from inflammation to proliferation: a critical step during wound healing. Cell Mol Life Sci. 2016;73(20):3861-85.

4. Gonzalez ACDO, Andrade ZDA, Costa TF, Medrado ARAP. Wound healing - A literature review. An Bras Dermatol. 2016;91(5):614-20.

5. Enggardipta RA, Haniastuti T, Handajani J. Efek eugenol terhadap jumlah sel inflamasi pada pulpa gigi molar tikus Sprague Dawley. Maj Kedokt Gigi Indones. 2016;2(2):66.

6. Brizuela C, Ormeño A, Cabrera C, Cabezas R, Silva CI, Ramírez V, et al. Direct Pulp Capping with Calcium Hydroxide, Mineral Trioxide Aggregate, and Biodentine in Permanent Young Teeth with Caries: A Randomized Clinical Trial. J Endod. 2017;43(11):1776-80.

7. Rosyida A. Evaluasi Radiografis Perawatan Direct Pulp Capping dengan Bahan Kalsium Hidroksida Tipe Hard Setting di RSGM UMY. Research Repository, Universitas Muhammadiyah Yogyakarta.2016.

8. Abubakar MB, Abdullah WZ, Sulaiman SA, Ang BS. Polyphenols as key players for the antileukaemic effects of propolis. Evidence-based Complement Altern Med. 2014;2014.

9. Rajoo M. The Role of Propolis in Inflammation and Orofacial Pain: A Review. Annu Res Rev Biol. 2014;4(4):651-64.

10. Budiarti. Ekspresi NF-kB dan Kolagen Tipe 1 Akibat Aplikasi Kombinasi Kalsium Hidroksida dan Propolis. Fakultas Kedokteran Gigi Universitas Airlangga. Karya tulis akhir. 2018.

11. Guyton \& Hall. Buku Ajar Fisiologi Kedokteran. Edisi 13. Jakarta: EGC; 2015.

12. Reyes-Carmona JF, Santos ARS, Figueiredo CP, Felippe MS, Felippe WT, Cordeiro MM. In vivo host interactions with mineral trioxide aggregate and calcium hydroxide: Inflammatory molecular signaling assessment. J Endod. 2011;37(9):1225-35.

13. Dwiandhono I, Effendy R, Kunarti S. The thickness of odontoblast-like cell layer after induced by propolis extract and calcium hydroxide. Dent $\mathrm{J}$ (Majalah Kedokt Gigi). 2016;49(1):17.

14. Poimenova A, Kitraki E, Kakaboura A, Rahiotis C. Early responses of human pulp to direct capping with resin adhesive systems and calcium hydroxide. Dent Mater. 2018;34(4):e73-82.

15. Baranwal R, Singh B, Dubey A, Avinash A. Review Article Calcium Hydroxide in Dentistry. Chettinad Heal City Med J. 2016;5(January):30-3.

16. Freires IA, De Alencar SM, Rosalen PL. A pharmacological perspective on the use of Brazilian Red Propolis and its isolated compounds against human diseases. Eur J Med Chem. 2016;110:267-79.

17. Ahangari Z, Naseri M, Jalili M, Mansouri Y, Mashhadiabbas F, Torkaman A. Effect of propolis on dentin regeneration and the potential role of dental pulp stem cell in guinea pigs. Cell J. 2012;13(4):223-8. 